\title{
Palm heart harvesting in the Brazilian Atlantic forest: changes in industry structure and the illegal trade
}

\author{
MAURO GALETTI*† and JOSÉ CARLOS FERNANDEZ \\ *Wildlife Research Group, Department of Anatomy, University of Cambridge, Cambridge CB2 3DY, UK; and \\ $\ddagger$ Department of Applied Economics, University of Cambridge, Cambridge, CB3 9DD, UK
}

\begin{abstract}
Summary
1. Until the late 1960s, Euterpe edulis was the most important edible palm species in the Brazilian markets. Since then, overharvesting of natural stands and the limited scope of plantations have caused the industry to shift to the multistemmed E. oleracea from the Amazon river estuary.

2. As a result of the relocation of the industry, the structure of the palm harvesting industry has changed and illegal trade has continued to exploit the remaining natural stands of E. edulis.

3. It is suggested that, to avoid the total harvesting of E. edulis and to achieve sustainable management of the palm heart, it will be necessary to diversify the local economy, create incentives for small land owners to improve their management practices, while keeping their competitiveness against the illegal trade, create the incentive of new sources of palm hearts and create a 'green stamping' for management palms.

4. Transformation of the illegal structure of the palm heart industry is probably the only solution to avoid the total depletion of the wild stands of E. edulis.
\end{abstract}

Key-words: Amazon forest, Euterpe edulis, frugivores, keystone species, sustainable management.

Journal of Applied Ecology (1998) 35, 294-301

\section{Introduction}

Palm hearts, known in Brazil as 'palmito', are the edible apical meristem (cabbage) of the palm tree used in salads, soups and many other dishes (Hodge 1965). Although various palm species have an edible heart, two species (Euterpe edulis Martius and E. oleracea Martius) provide most of the palm heart traded in Brazil (Strudwick \& Sobel 1988; Strudwick 1990; Alegretti 1994). The palm hearts of E. edulis (locally known as 'juçara' or 'palmito-doce') from the Atlantic forest, have long been exploited by indigenous populations. It is since the arrival of the first Portuguese in 1500 (Arroyo 1976; Camara Cascudo 1983), and particularly in the last few decades, that its exploitation has increased significantly (Alegretti 1994).

Euterpe edulis is restricted to the Atlantic forest (Henderson, Galeano \& Bernal 1995) and it is one of the most-studied palms in terms of silviculture (Carvalho 1994). This palm takes from 8 to 10 years to grow to the stage at which it can be harvested com-

(C) 1998 British Ecological Society $\dagger$ Present address: Departamento de Botânica, UNESP, CP 199, 13506-900 Rio Claro, São Paulo, Brazil. mercially (Carvalho 1994). Until the late 1960s, E. edulis was the most abundant source of palm heart in the Brazilian markets (Hodge 1965). To extract the palm heart from this single-stemmed palm, the tree has to be killed. Furthermore, the high demand and poor incentives for investment in adequate management practices has resulted in the depletion of most of the natural stands. At present, E. edulis is locally extinct in many parts of the Atlantic forest and its conservation status is considered as vulnerable (Dransfield, Johnson \& Synge 1988). Palms are harvested by few legal factories and several illegal domestic factories, but most of the palm hearts sold in markets are still from natural stands, despite some efforts to promote the plantation and management of palm trees (Ribeiro et al. 1993; Hering 1994).

As a result of the lower profitability of the palmheart harvesting in the exploited Atlantic forest, the industry moved to the Amazon River estuaries to exploit the multistemmed Euterpe oleracea (Strudwick \& Sobel 1988; Strudwick 1990; Clay 1995). By 1980, only $15 \cdot 6 \%$ of palm heart production, or $\approx 18$ tonnes worth US\$8.38 million, was produced in the southern region of the country (Alegretti 1994). Unfortunately, 
(C) 1998 British Ecological Society, Journal of Applied Ecology, 35, 294-301 the harvesting practices in the Amazon have been equally damaging, despite the fact that this palm could be harvested without killing the tree (Strudwick 1990; Clay 1995).

The collapse of the palm-heart industry in southern and eastern Brazil, however, has not meant the end of this activity. In the Atlantic forest harvesting of wild palms is still continuing, generating considerable employment and profits at the expense of further degradation. The trade structure has changed substantially, with illegal trade dominating the exploitation of the remaining natural stands of $E$. edulis.

The over-exploitation of E. edulis represents not only a loss of a palm-heart source, but also carries significant ecological costs. The fruits of E. edulis are important sources of food for avian and mammalian frugivores during the dry season (Laps 1996; Galetti 1996; Galetti \& Aleixo 1998). Moreover, the harvesting process destroys the understorey plants surrounding the palms and some frugivorous bird species are affected negatively in harvested areas (Galetti \& Aleixo 1998).

One of the objectives of this paper is to determine the factors behind the nature and persistence of the market for E. edulis, and to make comparisons with the trade in E. oleracea in Amazon forests. The trade structure in the illegal market in Sno Paulo state, particularly in the Vale do Ribeira region, one of the last strongholds of E. edulis populations, is investigated.

\section{STUDY SITE AND METHODS}

The study areas are located in Sete Barras and Registro, Vale do Ribeira, São Paulo, Brazil. The Vale do Ribeira has 14 main cities ( $\approx 235000$ inhabitants) and is known as the 'hunger belt' as it is the poorest region of the state. The main income for the population comes from banana and tea plantations in lowland areas. Unemployment is high since the banana plantations need few labourers and the income of each family is extremely low (less than US\$100-150 per month). This area still holds one of the largest forested areas in the whole Brazilian Atlantic rainforest. Several large state parks occur in the region, such as Intervales $\left(410 \mathrm{~km}^{2}\right)$, Carlos Botelho $\left(377 \mathrm{~km}^{2}\right)$, Juréia $\left(800 \mathrm{~km}^{2}\right)$ and Jacupiranga $\left(1100 \mathrm{~km}^{2}\right)$.

Vale do Ribeira is the stronghold of some threatened animals, such as the piping guan Pipile jacutinga (Galetti et al. 1997), and mammals, such as the woolly spider monkey Brachyteles arachnoides (Martuscelli, Petroni \& Olmos 1994), and threatened plants (palms and several Myrtaceae species).

From January 1994 to December 1995 a study of the interactions between E. edulis and birds was carried out at Parque Estadual Intervales, Sete Barras $\left(24^{\circ} 14^{\prime} \mathrm{S}, 48^{\circ} 04^{\prime} \mathrm{W}\right)$ (Galetti \& Aleixo 1998). During this period 10 palmiteiros were interviewed in addition to three middlemen in the small villages and three factory owners in Sete Barras and Registro. These interviews were made to estimate the amount of palms harvested, the prices of the hearts, and the extent of the illegal trade. The data were then compared with the data provided by the Police of Sete Barras and Registro on confiscated palm hearts.

\section{Results}

\section{SCALE OF THE ILLEGAL HARVESTING}

It is difficult to estimate the size of the illegal market, as harvest activities cannot be detected by satellite images and it is not necessarily related to logging. It has been estimated, however, that the volume extracted from the Vale do Ribeira is around 200 tonnes in each month (Ribeiro et al. 1993). In 1993, 54637 palm hearts in natura and 36113 jars were confiscated in the state of São Paulo (Florestar Estatístico 1993). Based on the mean weight of each heart $(500 \mathrm{~g})$, it is probable that $42365 \mathrm{~kg}$ is illegally harvested annually in the state.

In Sete Barras, a typical city where palm harvesting is a common practice, the police confiscated 20676 jars of $300 \mathrm{~g}, 3043$ jars of $1.8 \mathrm{~kg}$ and 3128 in natura hearts during 22 months (from January 1994 to October 1995) (Fig. 1). This indicates that around $7239 \mathrm{~kg}$ is confiscated annually (or 14479 palms). An interviewed middleman stated that up to one quarter of all truck loads were confiscated. One truck with 5794 of $300 \mathrm{~g}$ jars and 272 jars of $1.8 \mathrm{~kg}$ was confiscated in September 1995 in Sete Barras. The owner declared that he paid US\$20 000 for the jars and he would sell them for US\$45 000 in Sno Paulo city. When arrested, middlemen have to pay a fine of US\$35-170 to be released.

These figures indicate that the amount of E. edulis harvested illegally can reach around 29 tonnes annually in the Sete Barras region alone (or 57912 palms). The mean density of E. edulis in an unharvested forest is about 255 adult individuals per hectare (AlmeidaScabbia 1996) and it is likely that an area of 227 ha in Sete Barras region is harvested illegally every year. So, it is no surprise that native populations of this palm are declining quickly.

\section{MARKETS, PALMITEIROS AND MIDDLEMEN}

In 1990, there were 14 legal processing factories of palmito in Vale do Ribeira and many informal 'home factories' scattered within the Vale do Ribeira. The coast of the state of Paraná and Santa Catarina also has several illegal factories.

The industrial chain in palm-heart harvesting involves three distinct stages: the harvesting of the palm from the forest by palmiteiros, the transporting 


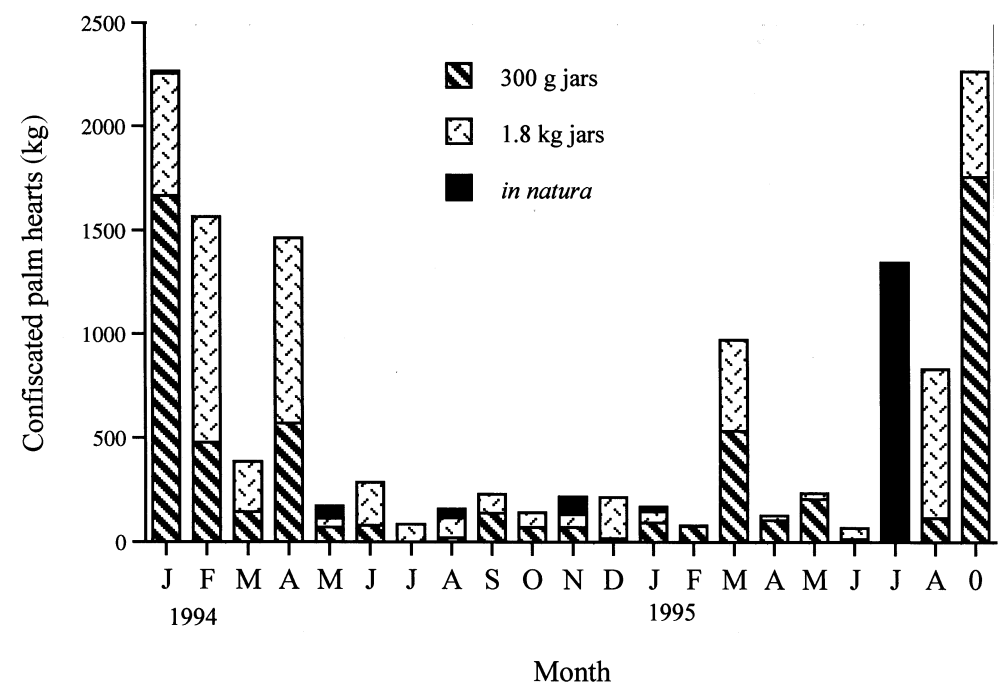

Fig. 1. Weight of confiscated palm hearts of Euterpe edulis in 1994 and 1995 in Sete Barras, Vale do Ribeira, Brazil. The estimates of in natura pieces were multiplied by the mean of each palm heart $(0.5 \mathrm{~g})$.

of palms to the cities, and their insertion into the legal trade.

\section{HARVESTING OF THE PALM HEART}

The palm is harvested both on private land and in state parks (hereafter called reserves) by palmiteiros. Extraction is prohibited in reserves, but they are continually being invaded by palmiteiros (Galetti \& Chivers 1995). The harvesting of palm hearts can be done in two ways: legally where the land owner must submit a management plan to the Instituto Brasileiro do Meio Ambiente e dos Recursos Naturais Renováveis (IBAMA), a federal agency, or in São Paulo to the Departamento Estadual de Proteção dos Recursos Naturais (DPRN), or illegally.

During legal palm heart harvesting on private land, the owner usually receives a rent for the matagem (the area designated for harvesting), from where all palms will be extracted. In 1993, the few legal matagem in the Estado de São Paulo were valued between US\$26 and $\$ 80 \mathrm{ha}^{-1}$ (Florestar Estatístico 1993). In comparison, in an illegal deal recorded in Sete Barras in 1995, a middleman paid US\$10000 for the exploitation of 5800 ha (US\$1.72 ha ${ }^{-1}$ ). This variability reflects regional differences, not only in the abundance of palms, since factory owners usually survey the land before negotiating the matagem, but also because of the low value that land owners place on the palm hearts.

The harvesting of palmito is an individual activity, with usually one man cutting and transporting the loads of $\approx 50$ hearts (bundle or feichos, see Strudwick 1990) of palm heart. Palmiteiros may be full-time harvesters or occasional workers who harvest palm during inactive periods on the banana plantations. The main difference between these palmiteiros and the pal- miteiros in the Amazon region, is the fact that the illegality of the activity has forced them also to cook and bottle the palm hearts in flasks while in the forest or at home.

Palmito harvesting is an important activity in the region. To appreciate the scale of the activity, take, for example, the town of Sete Barras. It had a population of 12467 in 1991 and the nearest forests are located within $3-25 \mathrm{~km}$ from the town. Palmiteiros travel these distances over hard terrain to reach the palms, which every year become more and more difficult to access. No precise information exists on how many people from Sete Barras are actually engaged in the palm heart harvesting activity, but palmiteiros themselves estimate that around a third of all males of working age participate in the activity. This very rough estimate suggests that there are at least 1000 palmiteiros in the Sete Barras region.

The seasonality and unpredictability of the banana activity has a large impact on the number of palmiteiros in the region. For instance, the flooding of many banana plantations in 1994 meant that in 1995 many workers were made redundant and forced to seek alternative employment as palmito harvesters. The inflow of workers to the activity has also been fuelled by the apparently attractive income that they derive from the palm, compared with work on banana plantations.

In reserves, palmiteiros work at night, when the probability of being caught is minimal. Given this risk, the heavy weight of the palm and the rapid oxidation of the heart, palms are stripped and cooked while still in the forest and only a few are taken home or to factories to be processed. Palmiteiros use citric acid and salt to cook the hearts in large metal pots in the forest. They keep glass jars supplied by the middlemen, so that most of the palm hearts leave the 
forest in a processed form. Once processed, they are stored until the middlemen collect them, usually every fortnight.

On private land, palmiteiros are usually contracted on a daily or weekly basis by middlemen who then drive them to the area and pay them either per palm or for each processed jar. The intensity of harvest varies widely among palmiteiros, primarily due to weather conditions. Some palmiteiros harvest every day, but most work around 15 days per month. The reduced harvesting period is due to the intensity of the policing activities by the Policia Florestal, who are the main constraint on their activities. Palmiteiros usually harvest an average of 10 'dozen' per week (a 'dozen', as described by palmiteiros, is two boxes of 15 jars of $300 \mathrm{~g}$ each). The number of palms required to fill a dozen has been increasing, as a result of the deteriorating natural stands. From 14 palms, the number has risen to 20 and even to 44 palms (Ribeiro 1986), indicating that the amount of effort needed to harvest a given number of dozens is increasing.

Palmiteiros sell the palms to the middlemen, who transport them to factories. In late 1995, palmiteiros received US\$22 per dozen without the jars or US\$30 with the jars, and hence, they get an average of US\$25 per dozen (i.e. US\$1.6 per $300 \mathrm{~g}$ jar). This means that the monthly income of an average palmiteiro is US\$500, which is five times the minimum wage in Brazil.

\section{MIDDLEMEN}

Middlemen are the link between the palmiteiros and the factories where illegal palmito is 'laundered'. Each middleman controls about 10 palmiteiros. With our previous estimate of 1000 palmiteiros, we would therefore expect some 90-100 middlemen in Registro and Sete Barras.

Each middleman transports between 200 and 250 dozen per month. He not only pays transport costs, but also pays the bribes and fines for the lorries that get confiscated. The middlemen are also the people who hire workers for the private lands. Most of the products they obtain are sold to the processing factories where they receive approximately US\$45 per 'dozen'. Alternatively, they may sell some of the larger hearts to restaurants and the small ones are cut in pieces ('picado') for the equivalent of US\$70-90 per dozen. However, these channels are limited, given the difficulties involved in marketing large quantities of illegal palmito.

\section{PROCESSING FACTORIES}

(C) 1998 British Ecological Society, Journal of Applied Ecology, 35, 294-301
There are five legal palm heart factories in Registro, each of which deals with a varied number of suppliers. These factories are the main supplier of supermarkets, and some even produce canned palm for export. Some factories purchase illegal palms from the middlemen and combine them with legal stocks that are then released to the market as legal palm heart. Part of the reason for their interest in the illegal palm is their need to keep the factory working at adequate capacity. One factory owner said that from producing $20000 \mathrm{~kg}$ per month in 1992, he has been forced to scale down production, and in 1995 he only produced half that amount, employing 30 workers and dealing with 15 middlemen. Some factory owners even stated that they bring some palms from the Amazon region to complement local production. It is these processing factories that provide the working capital for some of the operations in the field. For instance, they pay the matagem to land owners to explore their land.

After being labelled and canned, the product is sold to supermarkets throughout the entire state. The prices of a can of palm heart in the supermarkets in São Paulo city can vary by more than 200\% (M. Galetti, personal observation).

THE PALM-HEART INDUSTRY IN THE AMAZON ESTUARY: A COMPARISON

The Amazon estuary has seen a rapid development of the palm-heart industry over the past 35 years (Clay 1995). Today, it provides $95 \%$ of all palm hearts processed and consumed in Brazil (Alegretti 1994). In structure, the industry differs from that in the Atlantic forest, but it has been equally damaging and provides no incentives to manage the natural stands adequately.

The stands in the Amazon were not profitable enough to attract significant exploitation while the stocks in south-east Brazil were large enough to satisfy the market. As the availability of the palm from the Atlantic forest diminished and prices went up, the industry could afford to switch to more costly stands. The main limiting factor is the police patrolling on roads and in the factories. Factories in the Amazon are semimobile, with the capacity to move quickly to new stands, but the main bottleneck is the distribution channels out of the Amazon. It is also the distributors who place the highest price mark-ups in the industrial chain.

Distributors in Belém and others cities further downstream are central to the industry, and capture the highest share of the final price $(>95 \%)$ (Table 1$)$. There are many factories $(\approx 120)$ and they are poorly co-ordinated. The financial return to the palmiteiros is a low percentage of the final price of the product (0.6-1.7\%, Clay 1995), but they still get an average of 2-3 times the minimum wage in Brazil, which may compensate for the increased difficulties involved in finding and cutting the palms.

In contrast, in the Atlantic forest industry, lower transportation costs and perceived 'higher quality' of the palm (e.g. bigger size) have created higher prices. Additionally, the changes in the industrial structure, such as the processing at the harvesting level and the 


\begin{tabular}{|c|c|c|c|c|}
\hline $\begin{array}{l}\text { Harvest area/ } \\
\text { Stage of industry }\end{array}$ & Unit & $\begin{array}{l}\text { Amazon estuary } \\
\text { (1993) }\end{array}$ & $\begin{array}{l}\text { Vale do Ribeira } \\
\text { (1993): Legal }\end{array}$ & $\begin{array}{l}\text { Vale do Ribeira } \\
\text { (1995) }\end{array}$ \\
\hline Land owner & & & Legal & Illegal \\
\hline \multirow{3}{*}{$\begin{array}{l}\text { Forest rent for palm heart } \\
\text { exploitation }\end{array}$} & US\$ ha ${ }^{-1}$ & & $55 \cdot 47$ & $1 \cdot 72$ \\
\hline & US\$ dozen $\mathrm{eq}^{-1}$ & & $1 \cdot 84$ & $?$ \\
\hline & US\$ $(500 \mathrm{~g}) \mathrm{can}^{-1}$ & & $0 \cdot 18$ & $?$ \\
\hline \multicolumn{5}{|l|}{ Palmiteiro } \\
\hline \multirow[t]{2}{*}{ Palm in natura at cutting area } & US\$ dozen ${ }^{-1}$ & $0 \cdot 47-0.78$ or & $5 \cdot 27$ & \\
\hline & & $\begin{array}{l}0.24-0.39 \text { if sold to } \\
\text { middlemen }\end{array}$ & & \\
\hline \multirow[t]{2}{*}{ Processed palm in jars } & 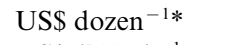 & & & 22 \\
\hline & $\mathrm{US} \$(300 \mathrm{~g})^{-1}$ & & & $0 \cdot 73$ \\
\hline Mean monthly earnings & US\$ & $135-200$ & & 500 \\
\hline Days/month harvesting & & $16-21$ & & 14 \\
\hline Number of palms harvested per day & & $150-200$ & & 96 \\
\hline Minimum wage in the region & US\$ month ${ }^{-1}$ & 67 & & 100 \\
\hline Distance travelled & $\mathrm{km}$ & $5-10$ & & $5-20$ \\
\hline \multicolumn{5}{|l|}{ Middleman } \\
\hline Palm in natura & US\$ dozen ${ }^{-1}$ & $0 \cdot 47-0.78$ & $6 \cdot 87$ & \\
\hline \multirow{2}{*}{ Processed palm in jars } & US $\$$ dozen ${ }^{-1 *}$ & & & 45 \\
\hline & US\$ $(300 \mathrm{~g})^{-1}$ & & & $1 \cdot 5$ \\
\hline Factory & & & & (Legal) \\
\hline \multirow[t]{2}{*}{ Processed palm in jars } & US\$ $(300 \mathrm{~g})^{-1}$ & $0 \cdot 08$ & $1 \cdot 65$ & $3 \cdot 00$ \\
\hline & US\$ $(1.8 \mathrm{~kg})^{-1}$ & $0 \cdot 50$ & $10 \cdot 68$ & $13 \cdot 00$ \\
\hline Processed in cans & $(500 \mathrm{~g}) \mathrm{can}$ & $0 \cdot 22$ & $2 \cdot 54$ & \\
\hline Number of factories & & 120 & & 14 \\
\hline Average production levels & tonnes month ${ }^{-1}$ & 29 & & $6-10$ \\
\hline Average workers per factory & & $15-30$ & & $15-20$ \\
\hline \multicolumn{5}{|l|}{ Distributor } \\
\hline \multirow[t]{2}{*}{ Processed palm in jars } & US\$ $(300 \mathrm{~g})^{-1}$ & $0 \cdot 33$ & & \\
\hline & US\$ $(1.8 \mathrm{~kg})^{-1}$ & $2 \cdot 00$ & & \\
\hline Processed in cans & US\$ $(500 \mathrm{~g})^{-1}$ & $0 \cdot 97$ & & \\
\hline Number of distributors & & 28 in Belem & & \\
\hline \multicolumn{5}{|l|}{ Supermarkets } \\
\hline \multirow[t]{2}{*}{ Processed palm in jars } & US\$ $(300 \mathrm{~g})^{-1}$ & & $3 \cdot 39$ & $5 \cdot 55$ \\
\hline & $\mathrm{US} \$(1.8 \mathrm{~kg})^{-1}$ & & $16 \cdot 32$ & $30 \cdot 50$ \\
\hline Processed in cans & US\$ $(500 \mathrm{~g})^{-1}$ & $5-6$ & $4 \cdot 05$ & $9 \cdot 10$ \\
\hline
\end{tabular}

* A dozen in this context is 2 boxes of 15 jars of $300 \mathrm{~g}$ each.

Data for Amazon were extracted from Clay (1995); for the Vale do Ribeira in 1993 the data were obtained from the Florestal Estatístico (1993) and from this study in 1995.

(C) 1998 British Ecological Society, Journal of Applied Ecology, 35, 294-301 illegal nature of much of the trade, have created a more evenly distributed share of the revenues across the industry. Palmiteiros in the Atlantic forest receive a higher share of the final price than in the Amazon forest, earning up to $7-8 \%$ of the final price (Table 1). This higher share may reflect both quantitative and qualitative differences, such as the greater effort required to extract palms (evidenced in the average palms per day harvested), the risk of being arrested and the higher cost of processing the palms in the forests. Thus, palmiteiros seem to work less and can earn up to five times the local minimum wage.

This higher share of the final price at the palmiteiros and middlemen levels are paid for by the factory owners due to the lower transportation costs and the ever-increasing prices for palm hearts. As a result, the share of the final price accruing to factories is smaller than in the Amazon (46-57\% of final price). In the Atlantic forest it is factories, and not distributors, who provide the money for the harvesting operations, so that their income also reflects their expected return on their investment.

\section{THE FATE OF EUTERPE EDULIS POPULATIONS}

The pattern of exploitation of E. edulis is the result of the investment decisions by the resource owners. The limiting factor of a biological resource, like a palm, is the growth rate of the plant. The market or consumptive value of the palm, coupled with its growth 
(C) 1998 British Ecological Society, Journal of Applied Ecology, 35, 294-301 rate make it an asset, i.e. something that can produce a flow of value to its owners, but biological assets require various inputs to ensure the generation of new resource and capturing of this return. It is not only necessary to invest in stocks of the resource (number of palms left to grow), but also on base resources (e.g. habitat and land) and management (e.g. monitoring and enforcement institutions).

The decision to invest in these subsidiary assets depends upon the relative return that the resource owner perceives from investing in this biological resource, compared with alternative uses (e.g. land conversion to agriculture or cattle ranching). The capacity of a species to provide a flow of benefits to resource owners, however, will depend upon the market value of the species, its growth rate and the socio-economic and regulatory environment in which they make decisions. Uncertainty over resource ownership, for instance, will contribute to the lowering of the asset value by lowering the expected future flow of values. Poor relative return of biological resources will typically mean its conversion to other alternative uses, i.e. the species will be completely extracted, sold, and the return will be used in more profitable investments.

The over-harvesting of palm hearts in the Atlantic forest and in the Amazon region is indicative of its perceived low value, which has created low incentives to invest in ancillary inputs. The market value of palm heart has simply helped to subsidize and provide some extra income for the conversion of land from forest to other uses like pasture and agriculture. Part of the reason for this is the low growth rate of the species (the species needs some 8-10 years to grow to harvesting age), but the fact that semi-intensive production methods, like intercropping with banana or the introduction of faster-growth species like the single-stemmed pupunha (Bactris gasipes), which grow in 3-5 years (Ribeiro 1986; Bovi, Godoy \& Saes 1991), have not increased significantly on private land is indicative of more fundamental distortions in the structure of incentives at the local level.

Moreover, the similar pattern of over-exploitation in the Amazon, despite the capacity to manage the palm without killing the tree (effectively shortening the rotation period), emphasizes that poor asset value seems to be dependent not only upon growth rates and technological restrictions.

The key element for enhancing investment incentives at the resource owner level is to enhance the asset value of palm hearts in the Atlantic forest. Under the current market structure in palm-heart exploitation in the Atlantic forest, rents are being created by virtue of the industries from the Amazon forest, but in less accessible areas land owners receive only a minor share of the value (Table 1).

Factories maintain control over access to the retail market and have exploited it to capture most of the rents from the activity. Under these circumstances, individual resource owners do not have any incentives to invest in the resource, and regulation should be targeted to improve the resource appropriation at the local level. In Brazil, palm-heart exploitation is regulated by Instituto Brasileiro de Recursos Renováveis (IBAMA) in all states, except in São Paulo where it is regulated by Departamento Estadual de Proteção dos Recursos Naturais (DPRN). The main regulatory strategy of these agencies has been to ban the unmanaged palm harvest and to establish requirements for the granting of licenses to exploit managed palm stands. These actions, however, have possibly had pervasive effects on the market, by enhancing the market power of middlemen and other agents who have the capacity to circumvent the regulations, and by increasing the initial investments (each management plan costs about from US\$10000 to US\$35000) required by resource owners to exploit palm heart legally.

\section{Conclusions}

With the transfer of the main palm-heart industry to the Amazon region, the Atlantic forest industry, while reduced, has not collapsed completely. The over-harvesting of the natural stands in the Amazon region and the monopoly power of the distributors in the Amazon, have contributed to the creation of rents for the remaining producers in the Atlantic region and have therefore encouraged the market to persist. Unfortunately, this persistence, accompanied by higher profits being shared among palmiteiros, has not been transferred to resource owners.

Resource owners face two alternatives for their palms: they either sell them legally, in which case they would have to incur all the initial investments required by law to obtain a license, or they can sell them to the illegal harvesters without a management plan. In the first option owners run higher risks on their investment and would be competing with overexploited natural stands. In the second option, they would not be paying the costs of management directly, since there is no investment upfront.

\section{RECOMMENDATIONS}

Today there is a heated debate in Brazil between the environmentalists that refuse to exploit and eat palm hearts, and the consumers and palm-heart factories (Orlande, Laarman \& Mortimer 1996). The Brazilian consumer is not likely to stop eating palm hearts, at least in the short term, since this delicacy has been used in the most typical Brazilian dishes for almost 500 years (Camara Cascudo 1983).

Analysis of the illegal and legal palm-harvesting structure and the consequences of both industries, together with some recommendations, are presented in Fig. 2. The recommendations presented here should be considered as part of the management practices of 


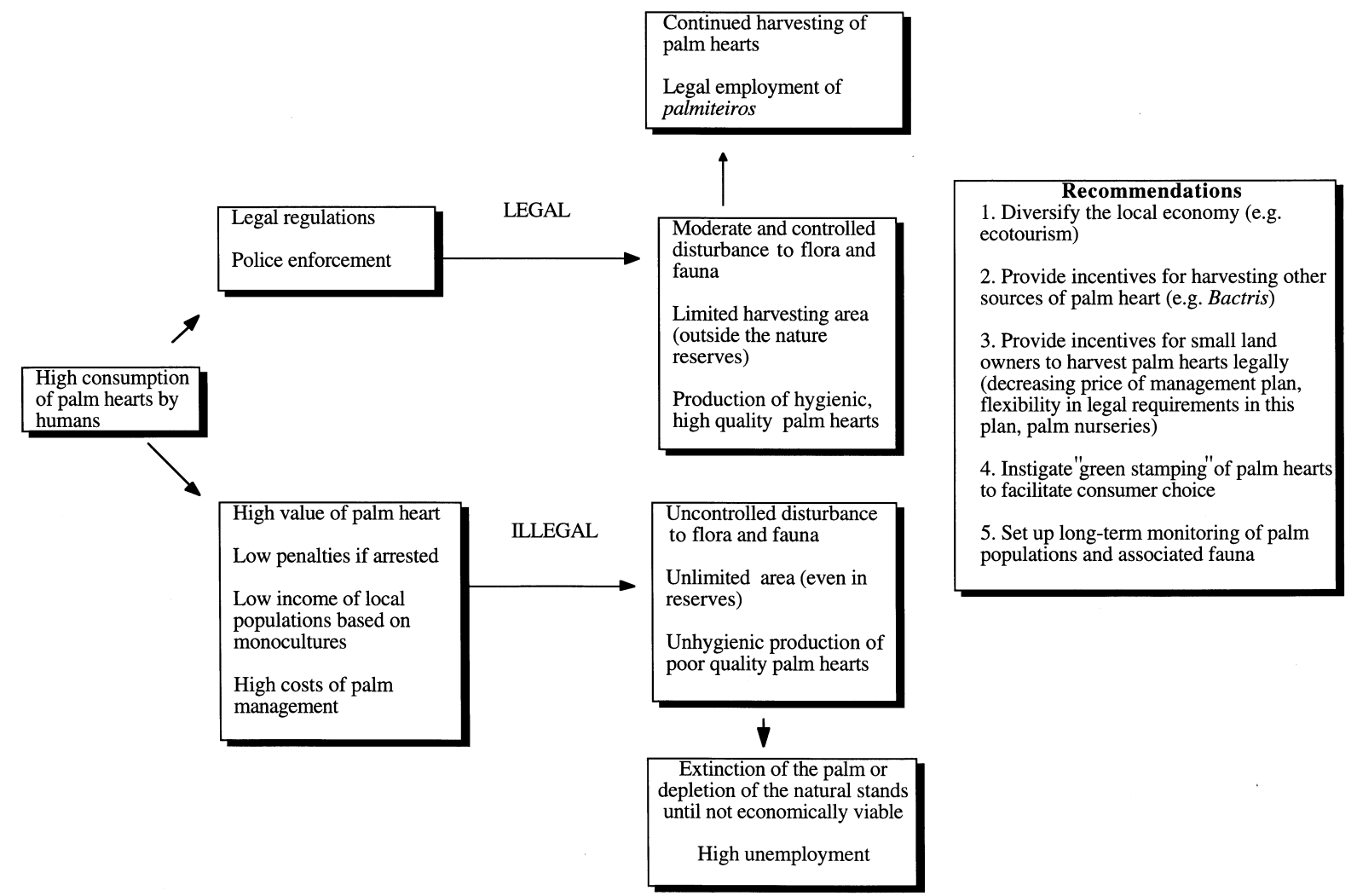

Fig. 2. Flow chart showing the causes and consequences of the harvesting structure of Euterpe edulis in Vale do Ribeira, São Paulo, Brazil, with management recommendations designed to avoid total depletion of natural stands.

(C) 1998 British Ecological Society, Journal of Applied Ecology, 35, 294-301
E. edulis in the Atlantic forest and possibly also applied to the Amazonian counterparts E. oleracea and E. precatoria. Orlande, Laarman \& Mortimer (1996) also pointed out that the extraction of palm hearts is very lucrative, but they do not provide any realistic alternative to control the illegal harvesting.

The low income of the rural populations in Vale do Ribeira, together with the high costs of the palm management plan, and the high value of palm hearts compared to any legal activity, make the illegal production a much larger activity (Table 1). As a consequence of this illegal activity the palm hearts are cooked under unhygienic conditions in the forest and most of them are small and poor quality hearts. In addition, the disturbance caused by illegal harvesting is relatively high when compared with undisturbed areas (Galetti \& Aleixo 1998).

At present there is an oversupply of manpower (palmiteiros) in the Vale do Ribeira. It is necessary to create new income for the local communities to complement banana and tea cultivation, in order to reduce the pressure on the resource from illegal harvesting. The incentive of the pupunha (Bactris) as another source of heart should be encouraged, but we do not recommend that native forest be logged for pupunha cultivation; instead we recommend that areas that have already been logged be developed as a new source of palm hearts.

It is also necessary to create incentives for small land owners that still have E. edulis within their properties.
Regulation must make palmito management more attractive rather than simply overharvesting in the illegal markets. This will require more flexibility than is present in the current legislation.

Moreover, the re-introduction and cultivation of $E$. edulis should be encouraged, so as to promote future palm management in a more sustainable way. In addition, it is important to control the sale of palms in supermarkets, and to introduce 'green stamping' so that 'management palms' can be easily distinguished from those originating from illegal factories. The role of the police in controlling illegal activities associated with palm harvesting is also essential, but the other alternatives presented here should help to reduce illegal activities.

If the current level of illegal activity continues, the wild populations of E. edulis will be totally harvested in the near future and once the palm has disappeared from the forests, its loss will eventually create a higher unemployment problem in Vale do Ribeira. Elimination of illegal activity is probably the best solution to avoid over-depletion of the remaining natural stands of E. edulis, and appropriate steps should be taken by policy makers and governments as a matter of urgency. Finally, it should be emphasized that the transformation of illegal activities into legal ones represents a cost and a long-term commitment for all parties involved: palmiteiros, resource owners, factories and mainly the consumer. 


\section{1}

M. Galetti \&

J.C. Fernandez

\section{Acknowledgements}

We are grateful to Polícia de Registro and Sete Barras for the data on confiscated palm hearts. We are also thankful to K. McConkey, S. Buzato, F. Olmos, A. D. Cuarón and two anonymous referees for comments on the manuscript. Financial support was provided by the Wildlife Conservation Society, World Wide Fund for Nature, John and Catherine T. MacArthur Foundation (through Fundação O Boticário de Proteção a Natureza), US Fish and Wildlife Service (through ICBP- PACS), and FMB. M. Galetti received a fellowship from the Brazilian Science Council (CNPq) and J. C. Fernandez from the Consejo Nacional de Ciencia y Tecnología, México.

\section{References}

Alegretti, M.H. (1994) Policies for the use of renewable resources: the Amazonian region and extractive activities. Extractivism in the Brazilian Amazon: Perspectives on Regional Development (eds M. Clusener-Godt \& I. Sachs), pp. 14-33. MAB Digest 18, UNESCO, Paris.

Almeida-Scabbia, R. (1996) Fitossociologia de um trecho de Mata Atlântica no sudeste do Brasil. MSc thesis, UNESP, Rio Claro.

Arroyo, L. (1976) A carta de Pero Vaz de Caminha: ensaio de informação a procura de contantes válidas de método. Melhoramentos, São Paulo.

Bovi, M.L., Godoy, G. \& Saes, L.A. (1991) Phenotypic correlations between characters of the palm heart tree Euterpe edulis Mart. and palm heart production. Revista Brasileira de Genetica, 14, 105-22.

Camara Cascudo, L. (1983) História da alimentação no Brasil, 2nd Vol. EDUSP, São Paulo.

Carvalho, P.E.R. (1994) Espécies florestais brasileiras. EMBRAPA-CNPF/SNI, Brasília.

Clay, J.W. (1995) The impact of palm harvesting in the Amazon estuary. Unpublished Report to World Wide Fund for Nature.

Dransfield, J., Johnson, D. \& Synge, H. (1988) The Palms of the World: a Conservation Census. IUCN, Cambridge.
Florestar Estatístico (1993) Informativo quadrimestral sobre o setor florestal paulista. Fundação Florestal, São Paulo.

Galetti, M. (1996) Fruits and frugivores in a Brazilian Atlantic forest. $\mathrm{PhD}$ thesis, University of Cambridge, Cambridge.

Galetti, M. \& Aleixo, A. (1998) Effects of palm heart harvesting on avian frugivores in an Atlantic rain forest of Brazil. Journal of Applied Ecology, 35, 286-293.

Galetti, M. \& Chivers, D.J. (1995) Palm harvest threatens Brazil's best protected area of Atlantic forest. Oryx, 29, 225-6.

Galetti, M., Martuscelli, P., Olmos, F. \& Aleixo, A. (1997) Ecology and conservation of the jacutinga Pipile jacutinga in the Atlantic forest of Brazil. Biological Conservation, 82, 31-9.

Henderson, A., Galeano, G. \& Bernal, R. (1995) Field Guide to the Palms of the Americas. Princeton University Press, Princeton.

Hering, K.G. (1994) Natural forest management in the Atlantic coastal rain forest of Brazil. Plant Research and Development, 40, 7-23.

Hodge, W.H. (1965) Palm cabagge. Principes, 9, 124-31.

Laps, R. (1996) Frugivoria e dispersão de sementes de palmiteiro (Euterpe edulis, Martius, Arecaceae) na Mata Atlântica, sul do Estado de São Paulo. MSc thesis, UNICAMP, Campinas.

Martuscelli, P., Petroni, L. \& Olmos, F. (1994) Fourteen new localities for the muriqui Brachyteles arachnoides. Neotropical Primates, 2, 12-5.

Orlande, T., Laarman, J. \& Mortimer, J. (1996) Palmito sustainability and economics in Brazil's Atlantic coastal forest. Forest Ecology and Management, 80, 257-265.

Ribeiro, J.H. (1986) SOS palmito. Globo Rural, 2, 18-30.

Ribeiro, R.J., Portilho, W.G., Reis, A., Fantini, A.C. \& Reis, M.S. (1993) O manejo sustentado do palmiteiro. Florestar Estatístico, 3, 15-6.

Strudwick, J. (1990) Commercial management for palm heart from Euterpe oleracea Mart. (Palmae) in the Amazon estuary and tropical forest conservation. Advances in Economic Botany, 8, 241-248.

Strudwick, J. \& Sobel, G.L. (1988) Uses of Euterpe oleracea Mart. in the Amazon estuary, Brazil. The Palm-Tree of Life: Biology, Utilization and Conservation (ed. A. B. Anderson), pp. 152-166. New York Botanical Garden, New York.

Received 27 November 1996; revision received 3 January 1998
(C) 1998 British Ecological Society, Journal of Applied Ecology, 35, 294-301 